\title{
Heavy mineral distribution in Weichselian drift successions in eastern Denmark
}

\author{
LISE HOLM
}

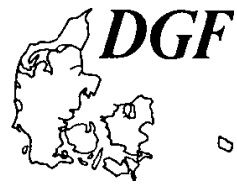

\begin{abstract}
Holm, L. 1981: Heavy mineral distribution in Weichselian drift successions in eastern Denmark. Bull. geol. Soc. Denmark, vol. 30, pp. 1-10, Copenhagen, November 12th, 1981. https://doi.org/10.37570/bgsd-1981-30-01

The use of heavy mineral content in Weichselian drift units as a stratigraphic tool has been investigated. A total of 26 heavy mineral analyses of representative samples from the four Weichselian kinetostratigraphic units in eastern Denmark are presented with data on both non-opaque and opaque mineral content. The heavy mineral content from inferred source areas has been deduced, partly from published data and partly from studies carried out by the author. The data indicate that heavy mineral analyses cannot be used as a general stratigraphic tool. However, the heavy mineral distribution indicates the occurrence of two distinct Weichselian heavy mineral provinces, a northern and a southern. The reasons why clast petrography studies may supply more reliable stratigraphic information are discussed.
\end{abstract}

Lise Holm, Geological Survey of Denmark, Thoravej 31, DK-2400 Copenhagen NV, Denmark, January 14 th, 1980.

\section{Introduction}

During the last decade, combined glacio-tectonic and stratigraphic investigations in eastern and southern Denmark have resulted in the establishment of a detailed kineto-stratigraphic classification of the Weichselian drift deposits (Berthelsen 1978, 1979; Petersen 1978; Sjørring 1977, 1978). This model forms an appropriate background for renewed studies concerning the glacial-stratigraphic significance of the (supposedly) provenance-dependant features of the drift deposits, such as their indicator boulder content, clast petrography, and heavy mineral content.

The present paper reports on a study of the non-opaque and opaque heavy mineral content of a total of 26 samples of known kineto-stratigraphic position and representing sediments from four Weichselian drift units in Denmark, see fig. 1 and 2 . The study was undertaken in order to clarify whether or not heavy mineral analyses can be used as a tool in glacial-stratigraphic correlations. Previous work on heavy mineral distribution in glacial deposits in Denmark has been made on Røgle Klint by B. Thomsen (pers. comm. 1977). This investigation showed that it was not possible to distinguish between stratigraphic different tills by mean of heavy minerals. In Germany Weiss (1958) was able to distinguish between Weichselian and Saalian deposits in Schleswig-Holstein on the basis of the heavy mineral content.

\section{Weichselian heavy mineral source areas}

According to the kineto-stratigraphic model, the Weichselian ice advances over eastern Denmark followed two main directions. They either came from the north or northeast (as during the first and the third main advance), or from the southeast (as during the second and the last main advance). Consequently, two major 'exotic' source areas and one 'local' can be deduced to have been responsible for the main supply of the clastic components of the four kineto-stratigraphic units (fig. 2). These three major source areas are: 1. The southwestern part of the Fennoscandian Shield from which area material was brought to Denmark from northern and northeastern directions.

2. The Baltic depression (and adjacent presentday land areas) from which area glacial advances approached the Danish islands from a southeastern direction - due to a clock-wise change in their flow direction.

3. The area of the Danish islands (and the adjacent present-day belts and shallow seas) where 


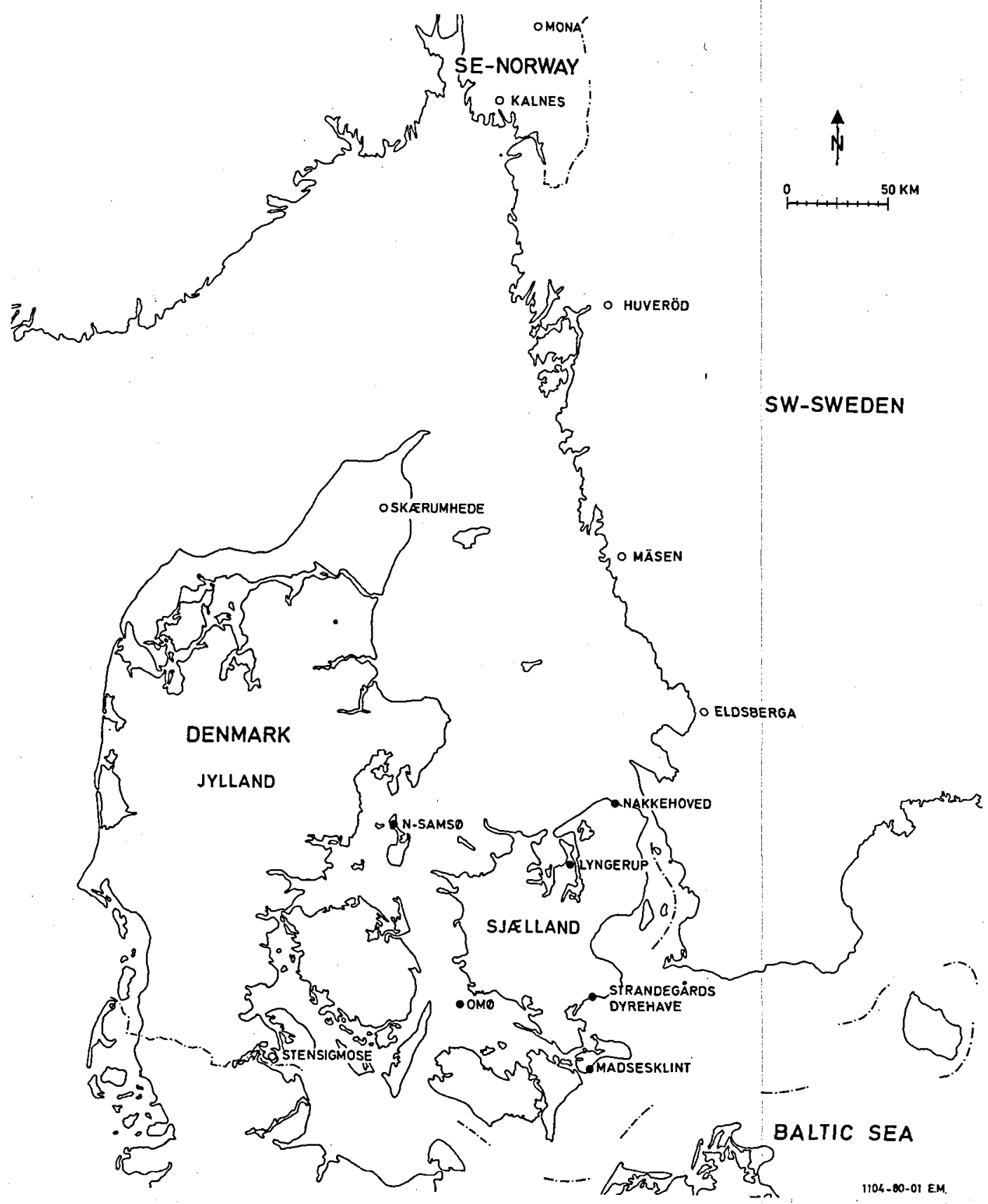

Fig. 1. Location map. Open circles indicate sampled localities representing source areas for the Danish Weichselian drift deposits. Dots indicate localities sampled in the Danish Weichselian drift deposits.

earlier Quaternary and pre-Quaternary deposits were exposed to glacial reworking. The material derived from this source area is called 'local' in the context of this paper - as opposed to the 'exotic' material from the more distant source areas 1 and 2 .

The heavy mineral associations supplied from each of the three source areas have been esti- 


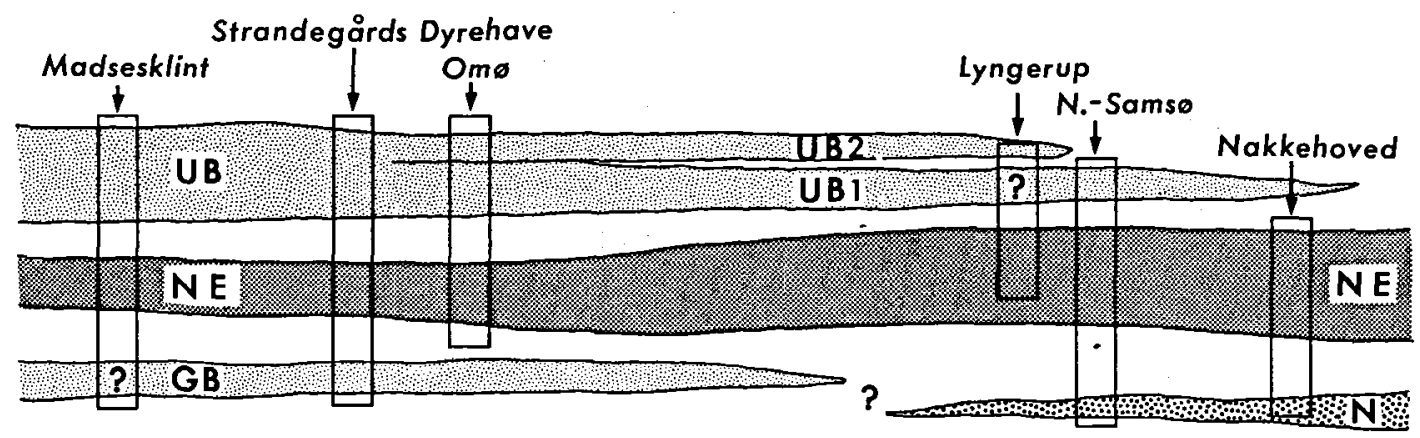

Fig. 2. Generalised N-S section through the Weichselian kinetostratigraphic units of eastern Denmark. The columns indicate the stratigraphic coverage of the sample series for each locality. N: Norwegian unit, GB: Old Baltic unit, NE: Northeast unit, and UB: Young Baltic unit. (After A. Berthelsen, pers. inf. 1977).

mated in the following way. The heavy mineral association derived from the southwestern Fennoscandian area was estimated from a study of glacio-fluvial and glacio-marine sands collected at 5 localities in SE-Norway and SW-Sweden (fig. 1) along major recessional deltaic ice border lines. Heavy mineral analysis from these 5 localities are shown in table 1 . These data were compared with available information of the 'upstream' bedrock composition (Holm 1977), and are believed to be representative for source area 1.

The heavy mineral association supplied from the Baltic depression (source area 2), was estimated from published data, in particular Füchtbauer \& Elrod (1971), Gry (1936), Jensen (1977) and Larsen (1966).

The heavy mineral association of the area of the Danish islands was also estimated from published data, in particular Bøggild (in Madsen et al. 1908), Friis (1976), Gry (1935) Larsen et. al. (1968).

As a further controle, two supplementary analysis were made: 1 ) on a sample from the Eemian Tapes sand from Stensigmose, southern Jylland (Konradi 1976), and 2) on a sample from the early Weichselian part ( $85 \mathrm{~m}$ below terrain level) of the Skærumhede boring II, northern Jylland (Bahnson et al. 1974). These two samples of marine clastic sediments are considered to be possible "average samples" for the southern and the northern part of the Danish island area respectively representing the last major sedimentary events before the onset of the Weichselian glaciations.

The results of the two analyses are shown at the bottom of fig. 3. They suggest that the area of the Danish islands does not constitute a homogeneous source area.

The heavy mineral associations that can be expected to have been supplied from the three different source areas are listed in table 2. From source area 1 , a very unstable heavy mineral association with a high hornblende percentage may have been derived, while areas 2 and 3 would hardly yield so immature and unstable associations. From these areas a hornblende percentage below 10-20\% could be expected. Both the Baltic depression and the area of the Danish islands are underlain by extensive areas of sediments and sedimentary rocks. For the area of the Danish islands no order of abundance of the common heavy minerals is shown due to the apparent inhomogenity of the area and due to lack of sufficient data.

\section{The Weichselian drift succession of eastern Denmark}

As shown in fig. 2, samples from 6 localities in eastern Denmark were investigated. In this figure, the kineto-stratigraphic position and coverage of the sample series collected at each locality are indicated. The samples from Nakkehoved represent the first and the third main 


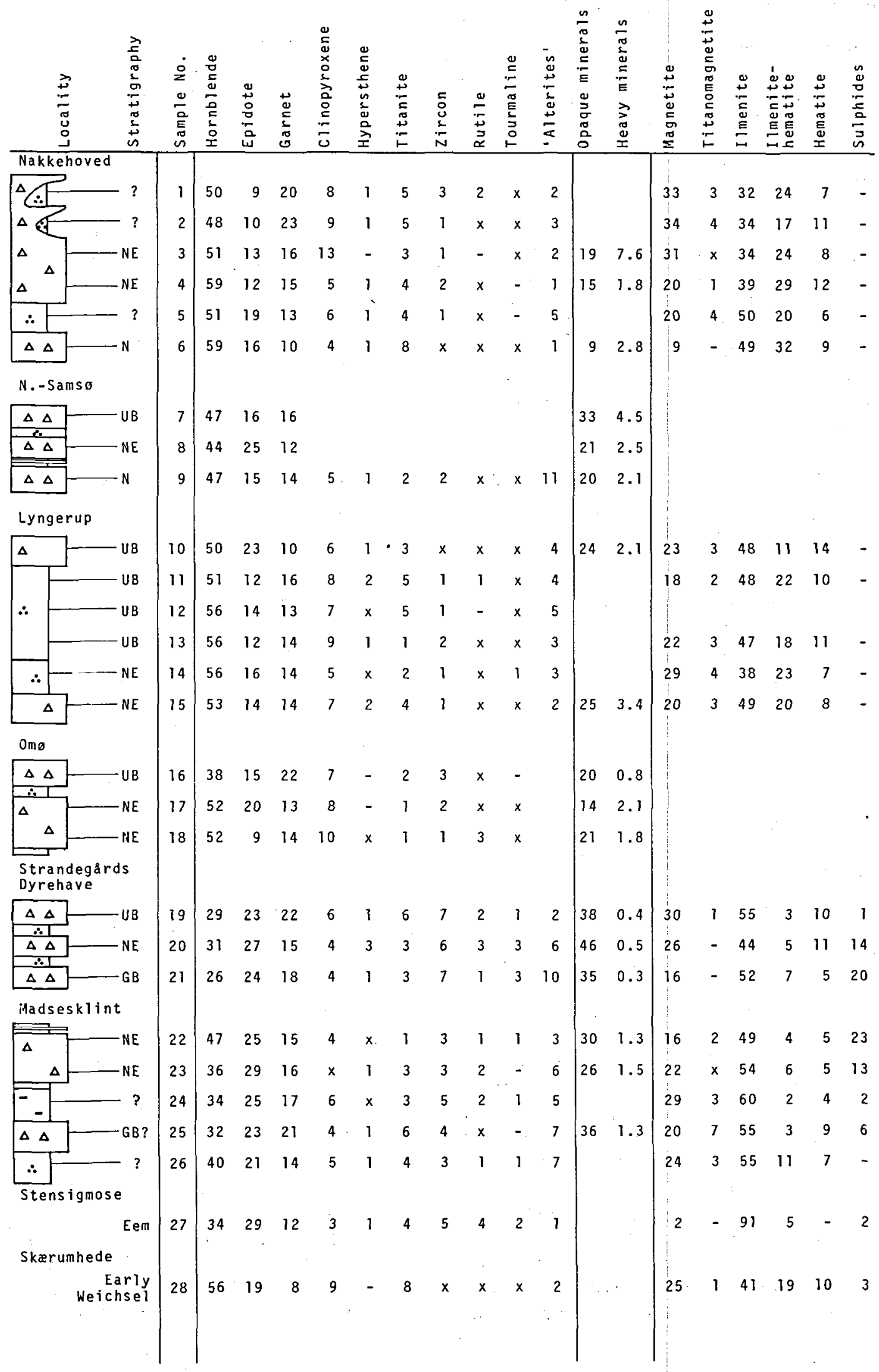


advances (respectively of the Norwegian ice and the NE-ice (Berthelsen 1974, Rasmussen 1974)).

The samples from northern Sams $\varnothing$ cover the same two units and in addition Young Baltic deposits (Houmark-Nielsen 1976). At Lyngerup, deposits from the NE-ice and the Young Baltic ice were sampled (Berthelsen, pers. information). From Omø (Jacobsen 1976), samples representing the NE-ice advance and Young Baltic advances were analysed. From the southern part of the area of investigation, the samples from Strandegård Dyrehave (Petersen \& Konradi 1974) comprise the Old Baltic, the NE- and the Young Baltic drift units, and the Madsesklint samples are of a supposedly similar stratigraphic position (Berthelsen et al. 1977).

From fig. 2 it may also be seen that the Norwegian advance and the Old Baltic advance apparently never overlapped each other in their geographic distribution, and the Young Baltic drift unit, due to a considerable readvance during the general retreat of the Young Baltic ice, locally comprises two subunits (Berthelsen 1978, Jacobsen 1976, Rasmussen 1975). Not shown, are the local readvances that occurred both during the general advance and retreat of the Norwegian and the NE-ice.

\section{Sampling and laboratory techniques}

With the exceptions of the NE-tills at Nakkehoved and Madsesklint which were sampled in their lower and upper parts, the analysed till samples are all composite and were obtained by mixing of randomly plucked samples from the unit in question. Glacio-fluvial deposits were sampled by channel sampling (Steinmetz 1962).

The till samples were wet-sieved on 3 and $4 \phi$ sieves $(125-63 \mu \mathrm{m})$. Sand samples were dried and sieved with $1 / 2 \phi$ intervals. The retained fraction was separated in bromoform $(\mathrm{d}=2.93$ $\mathrm{g} / \mathrm{cm}^{3}$ ) into a light and heavy fraction. The heavy fraction was in part mounted in Clearax $(\mathrm{n}=$ 1.66) for investigation in transmitted light, and in part in Epofix for polishing and study under the reflecting microscope. With a few exceptions (see text to fig. 3), 200 nonopaque and 200 opaque grains were counted according to the Band method (Kalsbeek 1965). Total heavy mineral and total opaque mineral percentages were not calculated for the glacio-fluvial sediments. The density-dependant sorting to which these have been submitted during their deposition, would render such percentages misleading. Investigations of heavy-mineral content versus grain sizes within the interval 63-707 $\mu \mathrm{m}$ revealed an almost identical relative distribution of the most common minerals in all grain-size subfractions. Further details about the treatment of the analytic data are given in the explanations to fig. 3.

\section{Results}

The heavy mineral analyses of the samples from the four Weichselian drift units of eastern Denmark are listed in fig. 3 . The sample series from each of the 6 localities are grouped according to their stratigraphic position. As may be read from fig. 3, the analyses do not permit age-different samples collected at the same locality to be distinguished. For instance, both the NE- and Young Baltic tills at Lyngerup have high hornblende-percentages (53\%, respectively $50 \%$ ) and low stable mineral (rutile, tourmaline, and zircon) percentages $(1 \%$, respectively $2 \%)$. Both the NE- and Young Baltic tills at Strandegårds Dyrehave have relatively low hornblende-percentages (31\%, respectively $29 \%$ ) and high stable mineral-percentages (12\%, respectively $10 \%$ ). So it seems that samples from a given locality show striking similarities in spite of their different kineto-stratigraphic positions.

The data, therefore, were treated and compared with respect to their content of horn-

Fig. 3. Heavy mineral distribution in Weichseljan deposits in eastern Denmark. The generalized stratigraphic columns to the left show the stratigraphic position of the samples. Triangles indicate till, dots melt-water sand, and dashes sift. Note that the kinetostratigraphic position of several meltwater deposits is uncertain. Abbreviations as in fig. 2 . Heavy mineral values are weight\%. The sums of the non-opaque as well as the opaque minerals are calculated in relation to $100 \%$ non-opaque heavy minerals. 200 nonopaque mineral grains and 200-270 opaque mineral grains were counted in each preparate, except the sample nos. 6,19 , and 27 in which respec. only 53,119 and 97 opaque mineral grains were counted, and the Om $\varnothing$-samples where 100 non-opaque mineral grains were counted. The grain-size fraction used was 63-125 $\mu \mathrm{m}$, except for the Omø-and Sams $ø$-samples where the 63-250 $\mu \mathrm{m}$ fraction was used. Trace is indicated by a cross. Only the most common minerals are listed. 


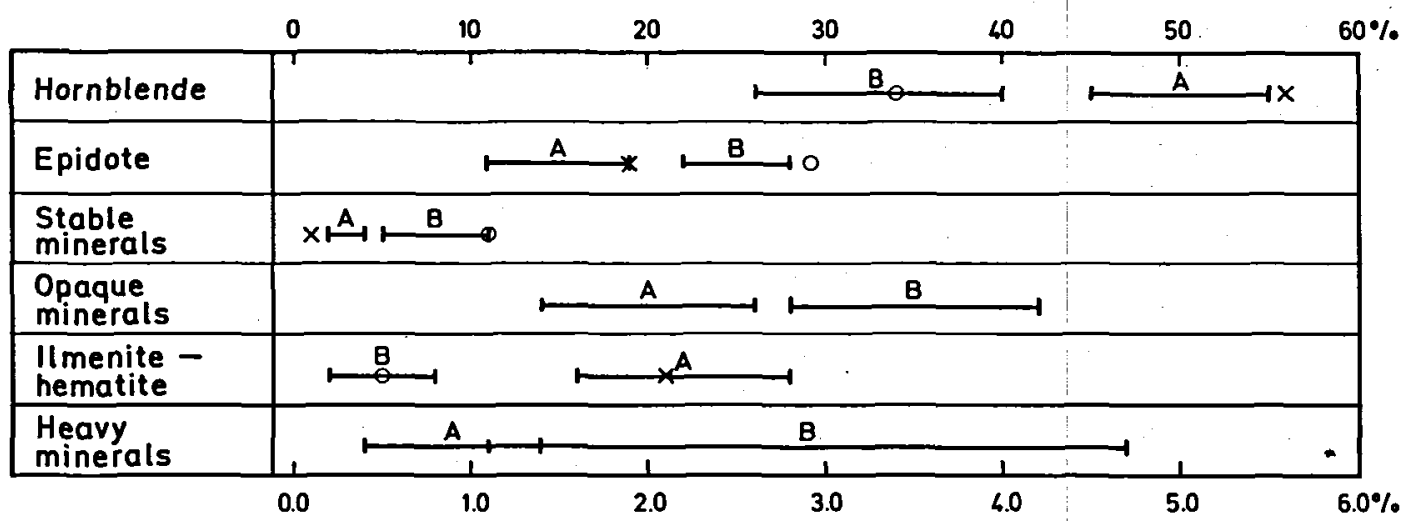

Fig. 4. Average heavy mineral composition of province A and province B. Only selected minerals and mineral groups are shown. The length of each bar indicate the mean plus and minus the standard deviation. A cross shows the position of the Skærumhede sample and a circle the position of the Eem sample. The exact values are listed in table 3.

blende, epidote, stable minerals, total content of opaque minerals, total content of heavy minerals, and ilmenite-hematite. For this purpose, the data were grouped into two groups: Group A comprising the localities northern Samsø, Nakkehoved, Lyngerup, and Omø, and group B embracing the Strandegård Dyrehave and Madsesklint localities, see fig. 4 . The mean and standard deviation for these minerals were calculated for each locality and for group A and group $B$ (table 3). The parameters were also calculated for two kineto-stratigraphic units, for the NEand Young Baltic unit. On fig. 5 hornblende is used as an example, showing two separated distributions when using group A and B classification, while the stratigraphic classification gives rise to two broad, overlapping distributions. The other minerals show more or less the same pattern, and no mineral has a distinct separation when using the stratigraphic classification.

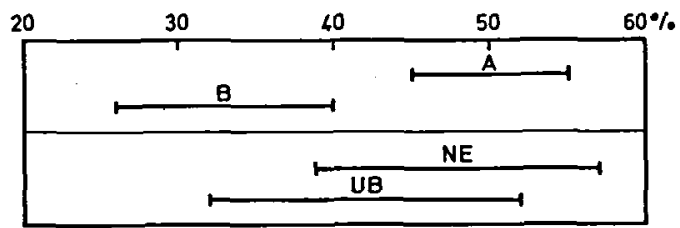

Fig. 5. Average values for hornblende, calculated for province $A$ and $B$ and for two kineto-stratigraphic units (Northeast and Young Baltic). The length of each bar indicate the mean plus and minus the standard deviation. The province classification results in two separated distributions while the stratigraphic classification gives rise to two broad, overlapping distributions.

\section{Discussion of the results}

The heavy mineral association found in the samples of group $\mathrm{A}$ is typically a very immature one. The total content of heavy minerals is rather high, the hornblende content high, and the content of stable minerals relatively low. On comparing with tables 1 and 2 , it becomes evident that this heavy mineral association probably was derived from source area 1 , north and northeast of the Danish islands as this area gives rise to very immature heavy mineral associations. Some admixture of local pre-Quaternary material might have occurred but only in restricted amounts - as shown by the high hornblende content recorded. Stone counts from northern Sjælland (Binzer 1974, Petersen \& Konradi 1974, and Sjørring 1973) support this view. In these counts, the exotic components (metamorphic and magmatic rocks) clearly dominate over local material (chert and chalk). A noteworthy admixture of early Weichselian marine sediments (originally deposited in the Skærumhede Sea) is known to have occurred during the deposition of the oldest, i.e. the Norwegian, drift unit. The Norwegian drift often contains $200-500$ admixed foraminifera per $100 \mathrm{~g}$ sediment. Content of this magnitude suggests a mixture in a ratio of up to 1:10 between local marine early Weichselian sediments and glacial material (Konradi in Petersen og Konradi 1974). Such an admixture would, however, hardly influence the heavy mineral distribution because of the northerly prove- 
nance of the admixed Skærumhede sediments (cf. fig. 3, bottom).

The heavy mineral association of group $B$ is not as immature as that of group $\mathrm{A}$. The hornblende content is lower, and both the epidote, and the stable mineral content a little higher. A comparison with table 1 and 2 , shows that the heavy mineral association of group B could represent a mixture of north-, and north-eastderived material (with high hornblende content), material from the Baltic depression, and presumable also material from the area of the Danish islands. No precise ratio of mixing can however be proposed.

Stone counts from southeastern Denmark (Bahnson 1973, Berthelsen, Konradi \& Petersen 1977, Binzer 1974) show that $70-80 \%$ of the clasts in the Weichselian tills of this region are of exotic origin and were transported over considerable distances due to repeated glacial reworking. The amount of Paleozoic limestone and shales (presumably originating from the Baltic depression) is about equal to that of metamorphic and magmatic rocks (largely of unknown origin). Thus, the stone counts do not conflict with the results of the heavy mineral analyses, and both methods intimate that all three source areas have contributed to the heavy mineral association of group B.

It is remarkable that there is a strong similarity between the heavy mineral content of the samples from the early Weichselian part of the Skærumhede sequence and the somewhat younger drift units of group A. Both are characterized by a relatively high hornblende and ilmenite-hematite content and a relatively low epidote and stable mineral content. The heavy mineral content of the marine Eemian sand from Stensigmose and the glacial sediments of group B are also very similar (relatively high epidote and stable mineral content, and a relatively low hornblende and ilmenite-hematite content) - and are all different from those of the group A samples. This suggests that two heavy mineral provinces can be distinguished in the Quaternary sediments of eastern Denmark, a northern province of northern and northeastern provenance, and a southern province of southeastern provenance (fig. 6). The only exception from this general pattern seems to be Omø where the Young Baltic unit has a slight ten-

\begin{tabular}{|c|c|c|c|c|c|c|c|c|c|c|}
\hline 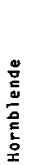 & 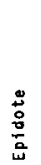 & $\begin{array}{l}\stackrel{\Delta}{\Delta} \\
\stackrel{5}{5}\end{array}$ & 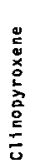 & 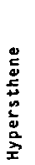 & 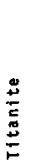 & 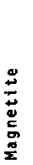 & 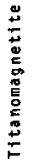 & $\begin{array}{l}\stackrel{\boldsymbol{\Perp}}{ \pm} \\
\underset{\mathbf{E}}{\mathbf{E}} \\
\stackrel{E}{\Xi}\end{array}$ & 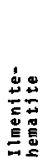 & 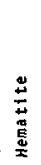 \\
\hline 58 & 8 & 22 & 6 & - & 5 & 39 & 3 & 17 & 32 & 8 \\
\hline 72 & 1 & 8 & 8 & 1 & 7 & 46 & 1 & 22 & 27 & 3 \\
\hline 35 & 38 & 6 & 5 & 1 & 9 & 31 & 4 & 27 & 28 & 10 \\
\hline 40 & 24 & 8 & 3 & 6 & 5 & 26 & 3 & 26 & 32 & 14 \\
\hline 38 & 25 & 6 & 13 & 4 & 7 & 38 & 8 & 15 & 31 & 8 \\
\hline
\end{tabular}

Tabie I. Heavy mineral distribution in sand trom recessional ice border lines in SE-Norway and SW-Sweden. The numbers shown are percentages. Non-opaque as well as opaque minerals are calculated equal to $100 \%$. Only the most common minerals are listed.

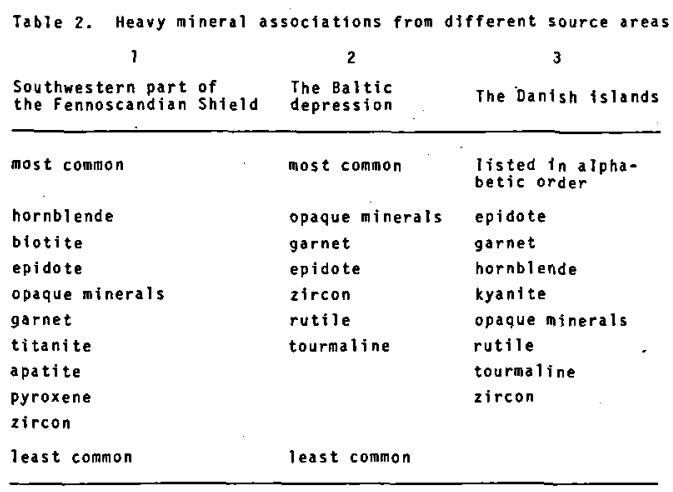

The data from source area 1 are based on the authors analyses (cf. table 1), from source area 2 on Fuchtbauer b Elrod (1971). Gry (1935). Jensen (1977), Larsen (1966), and from source area 3 on Baggitd (1n Madsen et al. 1908), frifs (1976), Gry (1935), and Larsen et al. (1968).

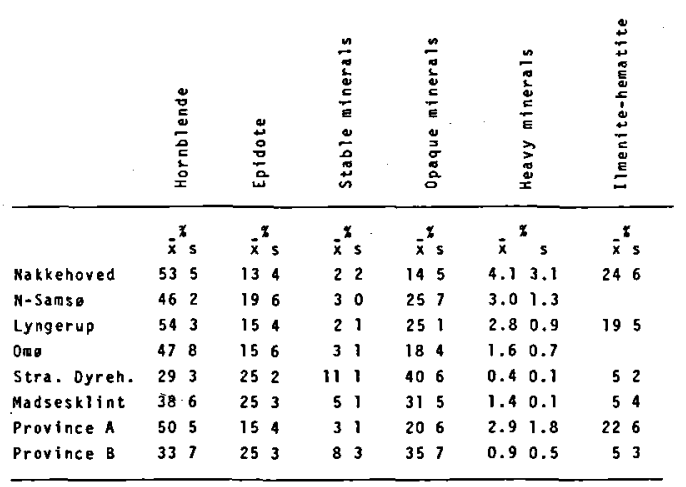

Table 3. Average heavy mineral composition of Weichselian deposits. Only selected minerals and mineral groups are listed.

dency to resemble the southern province (low hornblende and heavy mineral content). However, the over-all heavy mineral picture is more like the northern province and based on the three samples Om $\varnothing$ is included in the northern province. 

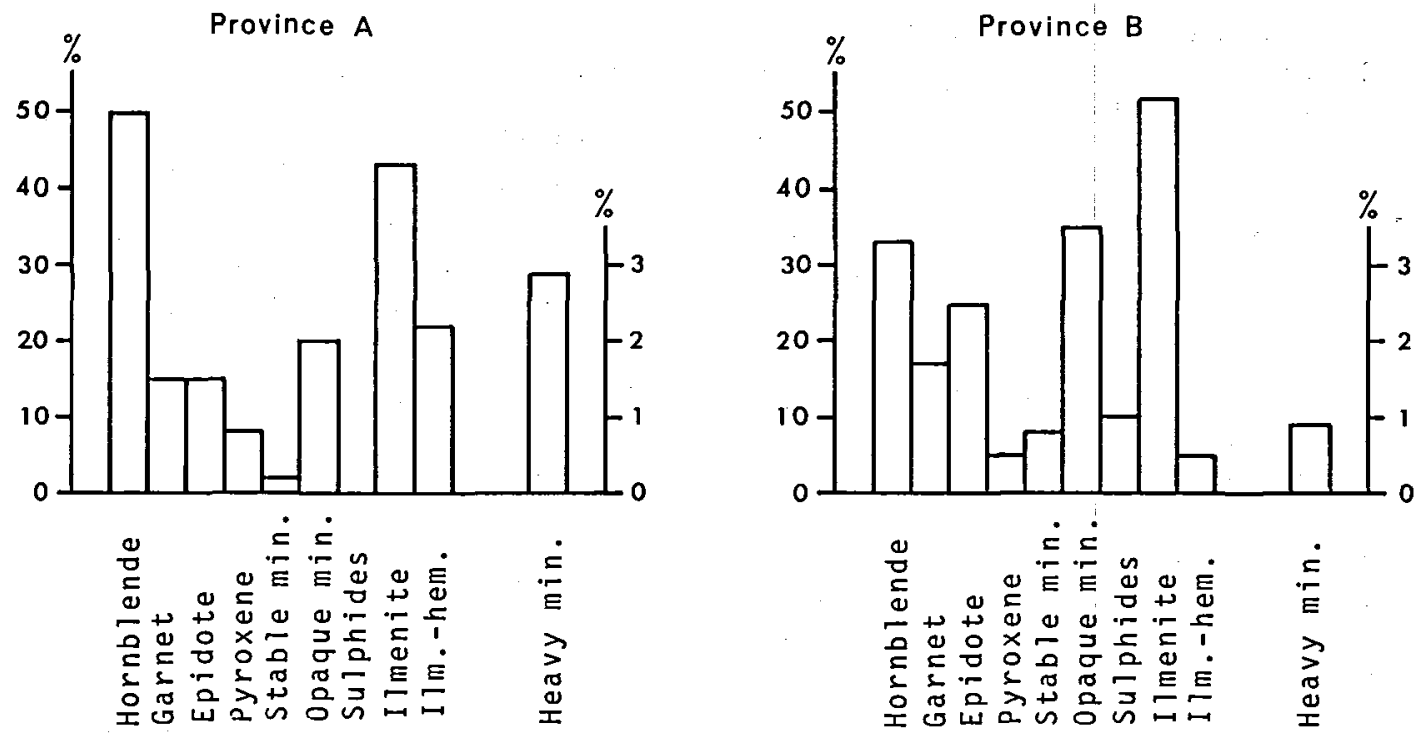

Fig. 6. Histograms illustrating the characteristics of the northern (group A) and the southern (group B) heavy mineral provinces in the eastern Danish Quaternary deposits (mainly Weichselian). Right-side scale refers only to the Heavy mineral values.

These two provinces appear to have exerted a strong control on the composition of the 63-125 $\mu \mathrm{m}$ fraction of the Weichselian drifts units so no correlation can be traced between glacial flow directions and the heavy mineral contents of the drift units.

The occurrence of unstable sulphides (pyrite makes up more than $95 \%$ of these) in the analysed sediments from southern Denmark, suggests some admixture of ?pre-Quaternary sediments (which contained authigenic pyrite). Sulphides have also been reported from recent beach sand (formed by wave-reworking of glacial sediments) at Rågeleje, northern Sjælland (Jensen 1967), but they are evidently of much more restricted occurrence in the northern part of the investigated area.

As regards the other opaque minerals observed it is more difficult to evaluate their significance. Their occurrence in pre-Quaternary sediments and rocks as well as their stability relationships during weathering and diagenesis, are imperfectly known. The fact that the ilmenite percentage is highest, and the ilmenite-hematite percentage lowest in the moderately immature association of group B, may however suggest that pure ilmenite grains are more resistant to secondary alterations than grains with ilmenitehematite exsolutions.

\section{Heavy mineral analyses versus stone count results}

The present investigation indicates that heavy mineral analyses cannot be used as a general method to differentiate stratigraphically different Weichselian glacial sediments in eastern Denmark. At first sight, this conclusion contrasts strongly with the fact that by means of stone counts it has been possible to distinguish between age-different tills at at least two of the localities discussed, i.e. at Strandegård Dyrehave (Petersen \& Konradi 1974) and Omø (Jacobsen 1976).

Why do stone counts, at least locally reflect stratigraphic positions, when counts of the 63$125 \mu \mathrm{m}$ fraction do not? This discrepancy may be due to several reasons. Among the most important ones are probably that mineral grains in general refer less clearly to a definite source area than rock fragments do, and that admixture of Tertiary sand, silt and clay deposits may have influenced the heavy mineral populations and not the clast petrography of the glacial sediments. Another matter: which might be of importance is that the matrix of tills in general is more homogenous than the clast distribution (May and Dreimanis 1976).

The factors - in unknown combinations - may 
cause the difference in the glacial-stratigraphic applicability of the stone count method and the heavy mineral method.

\section{Origin of the Quaternary heavy mineral provinces}

In the Quaternary deposits of eastern Denmark, two distinct heavy-mineral-provinces appear to exist, and within each province there is a marked similarity between the heavy-mineral associations of glacial deposits regardless of their kineto-stratigraphic position. This strongly suggests that a considerable admixture of pre-existing deposits must have taken place. The majority of this admixture material was of exotic origin and had been transported towards Denmark in connection with pre-Weichselian glacial events. In the northern province the material is of northern and northeastern derivation and in the southern province most of it is derived from the south-east.

At first sight this appears incompatible with the conclusion made by Binzer (1974). Based on analyses of both major and trace elements in the fraction less than $32 \mu \mathrm{m}$, he concluded that the Danish tills represent sediments of local origin and show a low content of exotic material. However, it can be proposed that the material from distant sources mainly consisted of sand (including the 63-125 $\mu \mathrm{m}$ fraction) and coarser fractions, while the admixed local pre-Quaternary material comprised (mainly) clay, silt, and some sand (derived mainly from the Tertiary). Thus the apparent conflict between Binzer's (1974) results and those of the present investigation can be explained. This theory is also in accordance with the conclusion of Hansen (1980) on the basis of palynology.

In conclusion, it is suggested that during the Quaternary glaciations, each advance deposited small amounts of juvenile exotic material and large amounts of locally derived material. However, due to the repeated advances, the total amount of exotic material deposited over eastern Denmark gradually increased, and during the Weichselian, most of the sand and coarser material that was taken up from local sources, must have been transported to Denmark from distant sources.
This mechanism of step by step transport and repeated admixture explains why glacial deposits of different age at nearby localities show the same or almost the same heavy mineral distribution. Naturally, the amounts of exotic supply and local admixture may have varied from advance to advance and from place to place, but in general any direction-controlled individuality of a till under formation would tend to become subdued by the control of inherent admixture. This control might have grown stronger and stronger during the Quaternary time.

Acknowledgments. The investigation reported on in this paper was carried out as a cand. scient. thesis project (Holm 1977) at Institut for almen Geologi, Copenhagen University, under the general supervision of professor, dr. phil. Asger Berthelsen. Lektor, cand. mag. B. Thomsen instructed me in the heavy mineral analysis, lektor, cand. mag. Aa. Jensen helped with problems concerning the identification of the opaque minerals. To all these persons I owe my sincere gratitude for inspiring help and assistance. John Miller B. Sc. kindly corrected the English language of the text.

Samples from the Samsø, Omø, Strandegård Dyrehave, Stensigmose and Skærumhede II-localities were ' kindly supplied by M. Houmark-Nielsen, E. Maagaard Jacobsen, P. B. Konradi, S. Sjørring and DGU (P. B. Konradi).

Finally, critically and constructive comments received from colleagues are acknowledged.

\section{Dansk sammendrag}

Hensigten med den foreliggende unders $ø$ gelse har været at opklare, om tungmineraler i kvartære aflejringer kan anvendes til at karakterisere bestemte stratigrafiske formationer/led og dermed adskille og korrelere disse.

Tre kildeområder for de østdanske Weichsel-aflejringer er udskilt. Disse er 1) pra-Weichsel aflejringer i Østdanmark, 2) den sydvestlige del af Det Fennoskandiske Skjold og 3) Østersa-egnen. Ud fra publiserede data og egne prøveindsamlinger er de sandsynlige tungmineralselskaber fra disse tre områder angivet (tabel 2). På denne baggrund er 26 tungmineralanalyser (non-opake og opake mineraler) fra 4 Weichsel kineto-stratigrafiske enheder prasenteret (fig. 3). Analyserne viser, at aflejringer fra samme lokalitet generelt har samme tungmineralindhold, uanset stratigrafisk placering. Derimod findes en regional forskel, således at en nordlig og en sydlig tungmineral-provins kan udskilles. Den nordlige har et tungmineralindhold meget lig det $i$ kildeområde 2 , og den sydlige har et tungmineralindhold, der kan være dannet ved en blanding af materiale fra alle tre kildeområder.

Denne regionale fordeling af tungmineralerne tyder på, at der $\mathbf{i}$ den enkelte glacigene aflejring må være skét en stor opblanding af aldre aflejringer. Hovedparten af dette opblandede materiale (sandfraktionen) er ikke af lokal Prækvartær oprindelse, men består af tidligere i Kvartærtiden tilført materiale. Hvert isfremstød har afsat lidt fjerntransporteret og meget lokalt materiale, således at hovedparten af materialet efter gentagne isfremstød klassificeres som fjernttransporteret, samt at de glaciale aflejringer fra samme område har næsten samme tungmineralindhold. 


\section{References}

Bahnson, H. 1973: Lithological investigations in some Danish boulderclay profiles. Bull. Geol. Inst. Univ. Upps. 5: 93109.

Bahnson, H., Petersen, K. S., Konradi, P. B. \& Knudsen, K. L. 1974: Stratigraphy of Quaternary deposits in the Skærumhede II boring: lithology, molluscs and foraminifera. Danm. geol. Unders., Arbog 1973: 27-62.

Berthelsen, A. 1974: Nogle forekomster af intrusivt moræneler i NØ-Sjælland. Dansk geol. Foren., Arsskr. 1973: 118-131.

Berthelsen, A. 1978: The methodology of kineto-stratigraphy as applied to glacial geology. Bull. geol. Soc. Denmark, Special Issue, 27: 25-38.

Berthelsen, A. 1979: Contrasting views on the Weichselian glaciation and deglaciation of Denmark. Boreas 8: 125132.

Berthelsen, A., Konradi, P. \& Petersen, K. S. 1977: Kvartære lagfølger og strukturer i Vestmøns klinter. Dansk geol. Foren,, Arsskr. 1976: 93-99.

Binzer, K. 1974: Sedimentological and geochemical features of Weichselian tills and pre-Quaternary sediments in Denmark. Danm. geol. Unders., Arbog 1973: 111-131.

Friis, H. 1976: Weathering of a Neogene fluviatile finingupwards sequence at Voervadsbro, Denmark. Bull. geol. Soc. Denmark, 25: 99-105.

Füchtbauer, H. \& Elrod, J. M. 1971: Different sources contributing to a beach sand, southeastern Bornholm (Denmark). Sedimentology 17: 69-79.

Gry, H. 1935: Petrology of the Paleocene sedimentary rocks of Denmark. Danm. geol. Unders. (2) 61: $171 \mathrm{pp.}$

Gry, H. 1936: Om Nexøsandstenen og "Aakerformationen". En tungmineralkorrelation. Meddr. dansk geol. Foren. 9: 27-42.

Hansen, J. M. 1980: Palynology of some Danish glacial sediments. Bull. geol. Soc. Denmark 28: 131-134.

Holm, L. 1977: En tungmineral-unders $₫ g e l s e$ af kvartaere aflejringer (et metodisk studie). (Unpublished cand. scient. thesis, Copenhagen Univ.: 99 pp).

Houmark-Nielsen, M. 1976: En glacialstratigrafisk oversigt fra Nordsamsø og Tunø. Dansk geol. Foren., Arsskr. 1975: 11-13.

Jacobsen, E. M. 1976: En morænestratigrafisk undersøgelse af klinterne på Omø. Dansk geol. Foren., Arsskr. 1975: 1517.

Jensen, Aa. 1967: Opaque minerals in the heavy beach sand from Rågeleje, Denmark. Meddr. dansk geol. Foren. 17: 21-36.
Jensen, Aa. 1977: Character and provenance of the opaque minerals in the Nexø sandstone, Bornholm. Bull. geol. Soc. Denmark, 26: 69-76.

Kalsbeek, F. 1965: On the origin of some banded amphibolites and gnei gneisses in the Belledonne Massif (French Alps) Neues Jb. Miner. Abh. 102: 177-188.

Konradi, P. B. 1976: Foraminifera in Eemian deposits at Stensigmose, southern Jutland. Danm. geol. Unders. (2), 105: $54 \mathrm{pp}$.

Larsen, G. 1966: Rhaetic-Jurassic-Lower Cretaceous sediments in the Danish Embayment (a heavy-mineral study). Danm. geol. Unders. (2), 91: 127 pp.

Larsen, G., Christensen, O.B., Bang, I. \& Buch, A. 1968: $\emptyset$ resund. Helsingør-Hälsingborg linjen. Danm. geol. Unders. Rapp. nr. 1: 90 pp.

Madsen, V., Nordmann, V. \& Hartz, N. 1908: Eem-Zonerne. Studier over Cyprinaleret og andre Eem-Aflejringer i Danmark. Nord-Tyskland og Holland. Danm. geol. Unders. (2), 17: $302 \mathrm{pp}$.

May, R. W. \& Dreimanis, A. 1976: Compositional variability in tills. I R. F. Legget (edt.) Glacial till. Roy. Soc. Can. Spec. Publ. 12: 99-119.

Petersen, K. S. 1978: Anwendung glaziotektonischer Untersuchungen bei der geologischen Kartierung in Dänemark. Eiszeitalter $u$. Gegenwart, 28: 126-132.

Petersen, K. S. \& Konradi, P. B. 1974: Lithologisk og palæontologisk beskrivelse af profiler i Kvartæret på Sjælland. Dansk geol. Foren. Arsskr. 1973: 47-56.

Rasmussen, L. Aa. 1974: Om morænestratigrafi i det nordlige Øresunds område. Dansk geol. Foren., Arsskr. 1973: 132-139.

Rasmussen, L. Aa. 1975: Kineto-stratigraphic glacial drift units on Hindsholm, Denmark. Boreas 4: 209-217:

Sjørring, S. 1973: Some problems in the till stratigraphy of the northeastern part of Sjælland. Bull. Geol. Inst. Univ. Upps. 5: 31-35.

Sjørring, S. 1977: The glacial stratigraphy of the island of Als, southern Denmark. Z. Geomorph. N. F., Suppl.-Bd. 27: 1-11.

Sjørring, S. 1978: Glacialtektonik und Glazialstratigraphie. Einige Beispiele aus Dånemark. Eiszetalter u. Gegenwart, 28: 119-125.

Steinmetz, R. 1962: Sampling and size distribution of Quartzose pebbles from three New Jersey gravels. J. Geol. 70: 56-73.

Weiss, E. N. 1958: Bau und Entstehung der sander vor der Grenze der Würmvereisung im Norden Schleswig-Holsteins. - Mayniana 7: 5-60. 